\title{
Utility of indocyanine green for diagnosing peritoneal dialysis-related hydrothorax
}

\author{
Jun Young Lee, Jae-Won Yang, Seung Ok Choi, Byoung-Geun Han \\ Department of Nephrology, Yonsei University Wonju College of Medicine, Wonju, Korea
}

\section{To the Editor:}

Hydrothorax is a rare but important complication of peritoneal dialysis (PD). Although its pathogenesis remains unclear, hydrothorax is common in women and occurs predominantly on the right side [1]. We describe a patient with PD-related hydrothorax, which was confirmed using the indocyanine green (ICG) clearance test.

A 78-year-old woman with diabetes-related end-stage renal disease who began PD 33 months prior visited Department of Emergency with shortness of breath. Ultrasonography revealed massive right-sided pleural effusion, and pleural fluid analysis revealed a transudative characteristic. Cytological and microbiological examination of the pleural fluid showed no abnormalities. There was no evidence of heart failure or liver cirrhosis. ICG was mixed with peritoneal dialysate and instilled (2 L) into the peritoneal cavity. Subsequently, we observed drainage of green-colored pleural fluid. No specific adverse effects occurred during the ICG clearance test.

No single definitive test has been established for accurate diagnosis and localization of the defect in the pleuroperitoneum in such cases, and each method has its disadvantages. The pleural fluid-to-serum glucose ratio ("sweet" hydrothorax) shows high sensitivity and specificity for detecting pleuroperitoneal communication;

Received August 20, 2018; Revised September 3, 2018;

Accepted September 4, 2018

Correspondence: Jun Young Lee

Department of Nephrology, Yonsei University Wonju College of Medicine, 20 Ilsan-ro,Wonju 26426, Korea.E-mail: junningnep@gmail.com ORCID: https://orcid.org/oooo-0001-8047-4190

Copyright (C) 2018 by The Korean Society of Nephrology

(a) This is an open-access article distributed under the terms of the Creative Commons Attribution Non-Commercial License (http://creativecommons.org/licenses/bync-nd/4.0/), which permits unrestricted non-commercial use, distribution, and reproduction in any medium, provided the original work is properly cited. however, a few patients demonstrate low pleural fluid-toserum glucose ratios [2]. The povidone-iodine addition test can be performed only in patients using icodextrin for PD [3]. The methylene blue test is not valid and may cause chemical peritonitis [1]. Peritoneal scintigraphy is expensive and exposes patients to radiation [1]. Notably, a few patients have negative findings, as was observed in our patient. Video-assisted thoracoscopy is an invasive intraoperative procedure [4]. In conclusion, the ICG clearance test may be a reliable, simple, safe, and inexpensive method of differentiating between pleuroperitoneal communication and other causes of transudative hydrothorax in patients with PD.

\section{Conflicts of interest}

All authors have no conflicts of interest to declare.

\section{References}

[1] Tang S, Chui WH, Tang AW, et al. Video-assisted thoracoscopic talc pleurodesis is effective for maintenance of peritoneal dialysis in acute hydrothorax complicating peritoneal dialysis. Nephrol Dial Transplant 18:804-808, 2003

[2] Momenin N, Colletti PM, Kaptein EM. Low pleural fluidto-serum glucose gradient indicates pleuroperitoneal communication in peritoneal dialysis patients: presentation of two cases and a review of the literature. Nephrol Dial Transplant 27:1212-1219, 2012

[3] Camilleri B, Glancey G, Pledger D, Williams P. The icodextrin black line sign to confirm a pleural leak in a patient on peritoneal dialysis. Perit Dial Int 24:197, 2004

[4] Lang CL, Kao TW, Lee CM, Tsai CW, Wu MS. Video-assisted thoracoscopic surgery in continuous ambulatory peritoneal dialysis-related hydrothorax. Kidney Int 74:136, 2008 